\title{
KIRJOITTAA TOISIN \\ KUIN NÄHDÄ
}

OUTI ALANKO-KAHILUOTO: Writing otherwise than Seeing - Writing and Exteriority in Maurice Blanchot. Helsinki: Yliopistopaino, 2007.

Maurice Blanchot (1907-2003), kirjailija, kirjallisuusteoreetikko ja filosofi, kuuluu sodanjälkeisen ranskalaisen ajattelun keskeisimpiin hahmoihin. Hänen monipuoliseen tuotantoonsa kuuluu niin romaaneja, kertomuksia, lehtiartikkeleita, esseitä kuin määrittelyä pakenevia fragmentaarisia kirjoituksiakin. Blanchot osallistui ja vaikutti elinaikanaan lähestulkoon kaikkiin viime vuosisadan ranskalaisen filosofian liikkeisiin ja virtauksiin, kuten fenomenologiaan, strukturalismiin, jälkistrukturalismiin ja dekonstruktioon. Aikalaisajattelijoista muun muassa Emmanuel Levinas, Georges Bataille, Jacques Derrida ja Michel Foucault ovat myöntäneet velkansa Blanchot'n ajattelulle.

Blanchot on silti toistaiseksi suhteellisen tuntematon henkilö filosofian ja kirjallisuuden tutkimuksen kentällä. Tämä voi johtua osin siitä, että hänestä yksityishenkilönä ei ole olemassa juuri minkäänlaista tietoa. Blanchot eli lähes täydellisesti eristäytyneenä julkisuudesta, joskaan hänen hiljaisuutensa ei tarkoittanut välinpitämättömyyttä maailmaa ja sen menoa kohtaan. Anonymiteetillä on Blanchot'n tapauksessa syvempiä merkityksiä kuin ensisilmäyksellä voisi ajatella. Persoonattomuuden teema, kirjallisuuden persoonaton kokemus, nousee yhdeksi Blanchot'n kantavaksi ajatukseksi.

Maurice Blanchot'n erikoislaatuisuus ajattelijana perustuu siihen, että häntä on hyvin vaikea lokeroida. Blanchot'n ymmärtäminen on myös tunnustetusti erittäin vaikeaa; hänen tekstinsä näyttäytyy lukemisen tasolla selvänä ja läpinäkyvänä, mutta sisällön ymmärtämisen ja tulkitsemisen kannalta kiistämättömän vaikeaselkoisena. Blanchot'ta on ajateltava rajojen rikkojana, ja leimallista hänen teksteilleen on määrittelemättömyys, joka ei suinkaan tarkoita epämääräisyyttä. Uransa alusta asti Blanchot haastaa teksteillään erottelun filosofisen diskurssin ja fiktiivisen kertomuksen välillä pakottaen kysymään, mikä on kirjallisuutta, mikä filosofiaa, missä menee raja tai onko sellaista edes olemassa.

Huolimatta Blanchot'hon kohdistuneesta lisääntyneestä akateemisesta kiinnostuksesta näkemisen ja näkymättömyyden jatkuvasti toistuva teema, näkemisen suhde kirjoitukseen Blanchot'n tuotannossa on Outi Alanko-Kahiluodon mukaan jäänyt toistaiseksi analysoimatta. Tämä näkemisen teema Blanchot'n tuotannossa on Alanko-Kahiluodon väitöskirjan Writing otherwise than seeing lähtökohta. Tutkimuksen ensisijainen viitekehys on sodan jälkeinen fenomenologinen keskustelu näkemisen, ajattelun ja kielen suhteista. (AlankoKahiluoto 2007, 13-14.)

Alanko-Kahiluodon mukaan Blanchot'n ajattelussa kieli rinnastuu katseeseen: katse on haltuun ottamista, subjektin valtaa objektiin nähden, ja kieli on tämän hallitsemisen väline. Erityisesti Blanchot'n fiktiiviset tekstit sekä myöhemmän tuotannon fragmentaariset kirjoitukset haastavat ajatuksen kielestä näkemisenä, paljastamisena ja ajatteluna, joina kieli on länsimaisen metafyysisen ajattelun piirissä totuttu ajattelemaan (Alanko-Kahiluoto 2007, 20). Blan- chot onkin kiinnostunut siitä, mikä kielessä ja kirjallisuudessa vastustaa näkyväksi tekemistä, mutta mitä silti täytyy yrittää jollakin tavalla tavoitella. Näkemisen ja näkymättömän suhde kielessä on Alanko-Kahiluodon mukaan Blanchot'lla paradoksaalinen. Kieli ei voi toimia ilman, että se nimeäisi asiat eli tekisi ne näkyviksi, mutta silti kieleen itseensä jää aina jotakin sellaista, mitä katse ei voi tavoittaa. Alanko-Kahiluoto tutkii väitöskirjassaan tapaa, jolla Blanchot tavoittelee tätä ylijäämää. Sen keskeinen kiinnostuksen kohde on Blanchot'n ajatus kielestä, joka pystyy vastustamaan katseen ylivaltaa ja joka ei perustu nimeämisen väkivallalle. (Alanko-Kahiluoto 2007, 12-13.)

Blanchot'n ajatteluun ovat vaikuttaneet lukuisat filosofit, joista Alanko-Kahiluoto nostaa esiin tutkimuksensa kannalta tärkeimpinä Hegelin ja Heideggerin. Alanko-Kahiluoto painottaa, että niin Blanchot'n ajattelua kuin koko 40-luvun ranskalaista Hegelkeskustelua värittää hyvin voimakkaasti Alexandre Kojèven tulkinta Hegelistä. Kojèvelainen käsitys Hegelin ajattelusta negaationa, kielen tuottamana murhana, on lähtökohta koko Blanchot'n ajattelulle. Alanko-Kahiluoto esittää, että Blanchot pyrkii ajatuksellaan kirjallisuuden kielen mahdollisuudesta vastustamaan Hegelin ajatusta, jonka mukaan nimeäminen negaationa tähtää lisääntyvään ymmärrykseen olemisen kokonaisuudesta: Hegelin mukaan kieli onnistuu lopulta paljastamaan olemisen totaliteetin ihmiselle (Alanko-Kahiluoto 2007, 185, 16-17).

Heideggerin vaikutusta Blanchot'hon Alanko-Kahiluoto tutkii kieltä koskevan kysymyk- 
sen kautta, joka yhdistää molempia ajattelijoita: onko ihmisen, jolle on annettu kieli, mahdollista saavuttaa tai tavoittaa ylipäätään mitään objektivoimatta sitä (Alanko-Kahiluoto 2007, 46)? AlankoKahiluoto painottaa tutkimuksessaan Heideggerin analyysia näkemisestä väkivaltana. Sen mukaan länsimaisen metafysiikan luoma analogia näkemisen ja läsnäolon välillä tuottaa ajatuksen näkemisen ylivallasta, näkemisestä tiedon edellytyksenä (AlankoKahiluoto 2007, 16). Näkeminen ja kieli taas ovat aina suhteessa toisiinsa: jokaisen lauseen perusta löytyy tavastamme nähdä ja havaita maailma, jossa olemme. AlankoKahiluodon mukaan Heideggerin ontologian tavoite on löytää totuudenmukaisempi tapa katsoa ja nähdä maailma, muodostaa avoimempi suhde olemiseen sinänsä. Onnistuakseen tässä Heidegger etsii totuudenmukaisempaa tapaa puhua olemisesta. Heideggerin tavoite on löytää kieli, jolla olemisesta voitaisiin puhua ilman ennakkooletusta subjektin metafyysisestä ideasta (Alanko-Kahiluoto 2007, 175-176). Alanko-Kahiluodon mukaan Blanchot yhtyy tähän tavoitteeseen. Niin Heideggerille kuin Blanchot'llekin kirjallisuuden tehtävä on tavoitella kieltä, joka ei perustu subjektin ylivaltaan objektiin nähden. Tällaisen kielen mahdollisuus avautuu kirjallisuudessa, runoudessa. Alanko-Kahiluoto tulkitsee Blanchot'n ajattelullaan kuitenkin myös haastavan Heideggerin käsityksen runoudesta. Siinä missä Heideggerille runouden on lopulta mahdollista paljastaa ihmiselle olemisen totuus, Blanchot'n mukaan kirjallisuudella ei ole tekemistä totuuden kanssa (Alanko-Kahiluoto 2007, 18).

Ongelma Blanchot'sta kirjoitettaessa on, kuinka kirjoittaa tieteellisesti kirjoittajasta, joka itse pakenee kaikkia määrittelyjä. Alanko-Kahiluoto tekeekin väitöskirjassaan viisaasti ja antaa Blanchot'n fiktiivisen tekstin puhua omasta puolestaan. Hänen keskeinen esimerkkinsä siitä, kuinka Blanchot'n kirjoitus lähestyy näkemisen ja kirjoittamisen ongelmaa, on Blanchot'n varhainen kertomus Thomas l'Obscur (Hämärä Thomas). Kertomuksessa Thomas joutuu jonkin sellaisen valtaan, jota ei voi tavoittaa eikä nimetä, mutta joka jatkaa olemistaan huolimatta Thomaksen yrityksistä kieltää se.

Alanko-Kahiluodon tutkimuksen päälähteet edustavat kuitenkin Blanchot'n teoreettisempia tekstejä 40-60-luvuilta. Alanko-Kahiluodon yhtenä päätavoitteena tutkimuksessaan on osoittaa, kuinka Blanchot'n ajattelu eroaa lopultaHeideggerin ajattelusta. Tämä erkaantuminen tapahtuu hänen mukaansa tuona aikakautena. Varhaisessa esseessään "Kirjallisuus ja oikeus kuolemaan" vuodelta 1949 Blanchot esittelee kirjallisuutta koskevia pääteesejään, jotka säilyvät jokseenkin samoina läpi hänen koko tuotantonsa, ja tästä syystä Alanko-Kahiluoto käyttää esseetä tutkimuksensa lähtökohtana (Alanko-Kahiluoto 2007 , 18). Blanchot esittää tuossa esseessään kaksi Alanko-Kahiluodon tutkimuksen kannalta tärkeää ajatusta: ajatuksen nimeämisestä murhana ja ajatuksen kirjallisuuden persoonattomuudesta, kielen mahdollisuudesta olla olemassa subjektista, lukijasta tai kirjoittajasta huolimatta.

Toisena päälähteenä ja ver- tailukohtana esseelle "Kirjallisuus ja oikeus kuolemaan" Alanko-Kahiluoto viittaa tutkimuksessaan Blanchot'n myöhäisempään teokseen $L^{\prime} E n$ tretien infini vuodelta 1969. Tällä kokoelmallaan filosofisia esseitä Blanchot kyseenalaistaa Alanko-Kahiluodon mukaan läpinäkyvyyteen, johdonmukaisuuteen, jatkuvuuteen ja lineaarisuuteen perustuvan tieteellisen kirjoittamisen ideaalin (Alanko-Kahiluoto 2007, 203). Esseet ovat fragmentaarisia, määrittelemättömiä ja niissä puhuu vähemmän väkivaltainen kieli (Alanko-Kahiluoto 2007, 18).

Kolmas Alanko-Kahiluodon päälähde ja tärkeä Blanchot'n teksti koskien kysymystä siitä, mitä kirjoittaessa tapahtuu, on ajallisesti näiden kahden kirjoituksen väliin jäävä vuonna 1955 julkaistu teos Kirjallinen avaruus. Sekä "Kirjallisuus ja oikeus kuolemaan" että Kirjallinen avaruus käsittelevät kuoleman ja kirjallisuuden suhdetta. Jälkimmäisen tekstin näkökulma on kuitenkin erilainen ensimmäiseen verrattuna. Siinä missä varhaisemmassa esseessä pääpaino on kielen tuottamalla murhalla, Kirjallisessa avaruudessa Blanchot lähestyy kirjallisuutta painottamalla kokemusta teoksen ja teon mahdottomuudesta. Kuten kuolemakin, kirjallisuus voi olla enintään kokemus; molemmat ovat kokemuksia siitä, mistä ei voi olla kokemusta, kokemuksia kokemuksen lopusta. Niin oma kuolemani kuin kirjallisuuskin ovat jotakin, josta "minällä" ei enää voi olla kokemusta. AlankoKahiluoto painottaa kirjallisuuden kokemuksen näyttäytyvän Blanchot'lle ajattelun sijaan lumoutumisena. Lumoutumisen käsitteellään Blanchot haastaa Alanko-Kahiluodon 
mukaan ajatuksen kirjallisuudesta intentionaalisena näkemisenä. (Alanko-Kahiluoto 2007, 126.)

Alanko-Kahiluodolle yksi koko Blanchot'n tuotannon olennaisimmista ajatuksista on ajatus kielestä yhtäaikaisesti sekä väkivaltana että ainoana mahdollisuutena tavoittaa toinen - tavoittaa mahdoton, jonka kieli nimeämisen ja negaation voimalle perustuvana unohtaa ja sulkee ulkopuolelleen. Blanchot ottaa tehtäväkseen etsiä kieltä, joka jättää käsitteet "toinen", "mahdoton" ja "nimeämätön" avoimiksi: kieltä, joka ei pyri hallitsemaan toista. (AlankoKahiluoto 2007, 221.) Myös Emmanuel Levinas nousee Alanko-Kahiluodon tutkimuksessa Hegelin ja Heideggerin rinnalle Blanchot'hon ilmeisesti vaikuttaneena ajattelijana. Blanchot ja Levinas kävivät koko elämänsä ajan kiivasta ajatustenvaihtoa siitä, mikä on kirjallisuuden ja filosofian suhde, mikä on ajattelun suhde kieleen ja kielen suhde toiseen. Blanchot'ta ja Levinas'ia yhdistää ajatus siitä, että filosofian traditiossa ja filosofisessa ajattelussa sama on määrittänyt aina toisen, toisen koskaan määrittämättä samaa. Alanko-Kahiluodon mukaan molempien ajattelijoiden mielestä sellaiset verbit kuin voir, pouvoir and savoir - nähdä, kyetä ja tietää - ovat filosofisessa diskurssissa aina hyvin lähellä toisiaan. Sekä Levinasin että Blanchot'n ajattelu tavoittelee mahdollisuutta lähestyä toista kielen avulla. Molemmat pohtivat, millaista olisi eettinen kieli: kieli joka tekisi oikeutta ulkopuolen, toiseuden ja vierauden kokemuksille. (Alanko-Kahiluoto 2007, 21-22.)

Alanko-Kahiluoto tutkii väitöskirjassaan, mitä Blanchot tarkoittaa puhuessaan kielestä väkivaltana. Esseessään "Kirjallisuus ja oikeus kuolemaan" Blanchot lähtee liikkeelle Alexander Kojèvelta lainatusta ajatuksesta, jonka mukaan Hegelin ajattelussa nimeäminen rinnastuu murhaan. Nimeäminen on tappamista: asian nimi on sen "hauta" ja nimeämisen mahdollisuus on asian poissaolon mahdollisuus. (Alanko-Kahiluoto 2007, 74.) Blanchot'n mukaan ihminen on kielen kautta tuomittu kykenemättömäksi lähestymään mitään ilman merkityksen synnyttämistä, asioiden nimeämistä eli merkitsemistä. Ihminen nimeää asiat ja olennot, hän hallitsee sanoja, eikä hän voi kohdata asioita ottamatta niitä haltuunsa. Nimeämisen myötä "henkilö joka on tässä ja nyt, voidaan erottaa itsestään, irrottaa olemassa- ja läsnäolostaan ja syöstä äkkiä tyhjyyteen vailla olemassaoloa ja läsnäoloa”. Sana ja nimi ovat olemisen poissaoloa. (Blanchot 2001, 21.)

Alanko-Kahiluoto kuvaa Blanchot'n suhdetta kuolemaan ja kieleen moniselitteisyytenä, kaksinapaisuutena: samalla kun Blanchot myöntää kielen lähtökohtaisesti väkivaltaisen luonteen kuolemana, hän pitää siitä kiinni kommunikaation ja toisen lähestymisen ainoana välineenä (Alanko-Kahiluoto 2007, 31). Kuolemasta ja murhasta tulee siis myös mahdollisuus. Ilman kuolemaa ei olisi kieltä, ilman kieltä ei olisi kommunikaatiota, ilmenemistä tai merkitystä. Kieli on Blanchot'lle ainoa tapa lähestyä "toista". Blanchot itse kirjoittaa: "Kuolema on ilmestynyt minun ja puhuttelemani olevan väliin mutta kuolema myös estää meitä joutumasta eroon toisistamme, sillä kuolemassa on ainoa yhteisym- märryksen mahdollisuus" (Blanchot 2001, 21). On kuoleman moniselitteisyyttä, että kielen tekemä murha luo myös yhteyden asioiden ja puhujan välillä. Vaikka negaatio eli kuolema erottaakin merkin objektistaan, se luo samalla merkityksen meille.

Alanko-Kahiluoto painottaa, että Blanchot'lle kielen väkivaltaisuus on väistämätöntä. Kirjallisuus tuntee kuitenkin kiinnostusta juuri sitä kohtaan, mikä pakenee kielen väkivaltaa: kielessä ilmenevää olemassa olemisen poissaoloa kohtaan. Esseessän "Kirjallisuus ja oikeus kuolemaan" Blanchot kirjoittaa, kuinka runous ei tyydy käsitykseen kielestä nimeäjänä, universaalina ja ideaalina, sellaisena kuin (Hegelin) filosofia sen näkee. Runous tavoittelee asioiden kadotettua läsnäoloa, olemassaoloa ennen kieltä ja tietoisuutta. Tekemällä itsensä kyvyttömäksi ilmaisemaan eli nimeämään, kirjallisuus haluaisi ilmaista juuri sen, minkä ilmaiseminen tuhoaa. (Blanchot 2001, 22-23.)

Mitkä ovat keinot, joiden avulla kirjallisuus pystyy erottautumaan väkivaltaisesta kielestä, lähestymään nimeämistä edeltävää hetkeä? Alanko-Kahiluodon mukaan Blanchot'lle kieli ei ole ainoastaan nimen, käsitteen tai idean tuottamista, vaan se on myös materiaa, se on tehty konkreettisista olioista, sanoista paperilla (AlankoKahiluoto 2007, 93). Blanchot itse kirjoittaa, kuinka ainoa toivo saavuttaa se, mikä työnnetään pois, perustuu kielen materiaalisuuteen. Blanchot'lle myös sanat ovat olioita, eräänlaista luontoa: kieli on "kirjoitettu olio, pala kaarnaa, sirpale kalliota, murunen savea, jossa maan todellisuus jää henkiin" (Blanchot 
2001, 22).

Tutkimuksessaan AlankoKahiluoto lähestyy mielestäni verrattain vaikeaselkoista materiaalisuuden ajatusta oivaltavasti Blanchot'n tekemän näennäisen kahtiajaon kautta: Blanchot tavoittelee kirjallisuuden kielen mahdollisuutta jakamalla kielen kahteen eri puoleen. Yhdellä puolella seisoo (hegeliläinen) filosofi, joka uskoo väkivaltaisen kielen eli negaation tuottavan totuuksia ja merkityksiä, toisella runoilija, jolle kieli on hyödytöntä, tuhlaavaa, ei-välineellistä. Kielen jälkimmäisellä puolella on selvää, että on olemassa aina jotakin, mitä nimeäminen ei pysty tavoittamaan. Alanko-Kahiluoto painottaa, että nämä kielen kaksi puolta ovat kuitenkin aina yhtä aikaa läsnä kielessä eli nimeämisen väkivaltaa ei voi välttää: kirjallisuuden kieli ei pääse siitä eroon. Mutta kirjallisuuden kieli pystyy kääntämään kielen väkivallan sitä itseään kohti. Se, että runous myöntää väkivallan olemassaolon, mutta ei itse syyllisty sen harhauttavaan lupaukseen eli yritä teeskennellä, että kaikki asiat olisivat nimettävissä ja korvattavissa käsitteillä, voi viedä kirjallisuuden kieltä vähemmän väkivaltaiseen suuntaan. (Alanko-Kahiluoto 2007, 91.) Blanchot kirjoittaa, kuinka kirjallisuudelle kieli ja sanat ovat materiaalisia olioita läpinäkyvien käsitteiden sijaan. Kieli ei ei enää yritä olla pelkkää merkitystä vaan se "yrittää tehdä itsensä mielettömäksi”. Sana ei toimi enää kuin ideaali, vaan siitä tulee alkuaine, "ei enää nimi vaan pikemminkin hetki yleismaailmallista nimettömyyttä, puhdas myöntö, tyrmistyttävää kasvotusten oloa hämäryyden syvyydessä." (Blanchot 2001, 21.)
Alanko-Kahiluodon mukaan Blanchot tavoittelee materiaalisuuden kautta kieltä, jolla olisi pääsy johonkin sellaiseen, mihin nimeämisen kielellä ei ole pääsyä: asioiden olemassaoloon sellaisenaan, ilman, että ne alistettaisiin objekteiksi. Toisin kuin kielen ensimmäinen puoli, joka luottaa totalisoivaan asioiden näkyväksi tekemisen mahdollisuuteen, toinen puoli kielestä myöntää asioiden poissaolon mahdollisuuden. Tästä tulee Blanchot'lla myös kirjallisuuden merkityksen välttämätön ehto. Sanalla on merkitystä vain, kun se riistää meiltä objektin jonka se nimeää. (Alanko-Kahiluoto 2007, 93-94.)

Materiaalisuudessa ja siitä seuraavassa kirjoitetun merkin toistamisen mahdollisuudessa piilee Alanko-Kahiluodon mukaan Blanchot'n kirjallisuuden kielen mahdollisuus (Alanko-Kahiluoto 2007, 33-34). Merkki materiaalisena oliona, irrotettuna perinteisestä metafyysisestä kontekstista, jota määrittää pyrkimys tietoon, on toistettavissa. Merkki itsessään toistettavana ei katoa. Toistettavina sanojen on mahdollista jatkaa olemassa olemistaan itsenäisesti, yksittäisen subjektin tietoisuudesta riippumatta. Päin vastoin kuin esimerkiksi Husserlilla, jonka mukaan subjektin tietoisuus on merkityksen alkuperä, Blanchot'lla sana oliona jatkaa merkitystään kirjoittavan ja lukevan subjektin takana: materiaalisuus ja merkin toistettavuus ovat ehtoja sille. (Alanko-Kahiluoto 2007, 106.)

Alanko-Kahiluodon mukaan kielen materiaalisuus mahdollistaa Blanchot'n ajatuksen kirjallisuudesta persoonattomana kokemuksena. Tarttumalla materiaalisuuteen ideoi- den sijaan kirjallisuus alleviivaa omaa autonomisuuttaan ja ulkopuolisuuttaan, riippumattomuutta subjektista. Koska kirjallisuus näkee kielen muuna kuin käsitteinä, se ei tarvitse perustakseen nimeäjää eli husserlilaista kirjoittajan intentionaalista tajuntaa. Kirjallisuuden kielen tarkoitus on tehdä ilmeiseksi, että kirjallisuudella ei ole lähdettä, joka voitaisiin identifioida persoonaan tai tiettyyn määriteltyyn kontekstiin. Materiaalisuuden avulla se onnistuu tässä: se virittää kielelle ansan itseensä. Painottamalla kielen materiaalista puolta, tekemällä itsestään hyödyttömän ja hämärän, kirjallinen kieli kieltäytyy filosofian kielen tavoitteesta; se kieltäytyy valaisemasta ja paljastamasta. (Alanko-Kahiluoto 2001, 91-94, 110.) Alanko-Kahiluodon mukaan kielen toisen puolen eli kirjallisuuden tehtäväksi tulee muistaa sen olemassaolo, minkä kielen ensimmäinen puoli unohtaa. Niinpä kirjallisuudesta tulee kysymistä, kysymistä omasta olemuksestaan. Kirjallisuus kysyy, mitä löytyy ilmeisen takaa, mitä unohdetaan, kun kielen pyrkimyksenä pidetäänymmärtämistä ja representoimista. (Alanko-Kahiluoto 2007, 94.)

Alanko-Kahiluodon tulkinnan mukaan Blanchot'n kirjallisuuden kieli syntyy siitä huomiosta, että kielen ulkopuolelle jää aina jotakin, mitä kieli itse ei pysty selittämään tai käsitteellistämään. Tämä jokin on asioiden alkuperäinen olemassaolo, jota lukija ei pysty hallitsemaan "mentaalisella silmällään" ja jonka kirjallisuus haluaa tavoittaa. (Alanko-Kahiluoto 2007, 101.) Blanchot kirjoittaa, kuinka filosofia voi valehdella itselleen, että kissa on kissa, ikäänkuin elävä kissa ja sen nimi 
olisivat sama asia. Niin ei kuitenkaan Blanchot'n mukaan ole: kissan nimeäminen on sen tekemistä ei-kissaksi, kissaksi, joka on lakannut olemasta. Kissan nimestä tulee idea. Nimetessään kieli unohtaa asian olemassaolon sellaisena kuin se on, ja tätä unohdettua olemassaoloa kirjallisuuden on tavoiteltava hetkeä ennen nimeämistä, hetkeä ennen kuin olemassa olevasta tulee oleva. Ollakseen olemassa kirjallisuuden on etsittävä jatkuvasti tätä ulkopuolta, vaikka se on Blanchot'lle väistämättä "traaginen yritys". (Blanchot 2001, 21, 23.)

Miksi kirjallisuus haluna tavoittaa kieli ennen nimeämistä on Blanchot'lle traaginen yritys? Tämä traagisuus viittaa ymmärtääkseni siihen, ettei runouden kieli voi päästä merkityksen ulkopuolelle. Yrittäessään etsiä totuutta ennen kieltä se törmää vain oman merkityksensä loputtomaan jatkumiseen. Kun kirjallisuus ei halua nimetä asiaa eli merkitä, se huomaa, että myös merkityksettömyydellä, merkitsemättä jättämisellä on merkitys. Blanchot itse kirjoittaa, että vaikka ilmausten tarkka merkitys onkin hävinnyt, "nyt vahvistaa itsensä merkitsemisen itsensä mahdollisuus, merkityksen antamisen tyhjä voima - outo persoonaton valo" (Blanchot 2001, 23). Alanko-Kahiluoto esittää, että samalla kun kieli Blanchot'lla perustaa itsensä kuolemalle, se myös estää kuolemaa toteutumasta: kieli merkitsee mahdottomuutta olla merkitsemättä ja merkityksen ikuista paluuta. Vaikka kieli kieltäisikin sanan merkityksen, kiellon merkitys jatkaa merkitsemistään. Näin ollen kirjallisuudesta tulee kokemus, jossa tietoisuus löytää olemisensa kyvyttömyytenä menettää tietoisuuttaan. Kun merkitystä ja tietoisuutta ei voi paeta, tästä kokemuksesta tulee piina, tunne loputtomasta kuolemisen prosessista. (Alanko-Kahiluoto 2007, 116.)

Alanko-Kahiluodon ajatus on siis, että Blanchot'lla merkityksen loputtomuus rinnastuu ikuiseen kuolemiseen. Kuolema näyttäytyy nyt mahdottomuutena kuolla, ikuisesti jatkuvana kuolemisena, joka ei voi toteutua kuolemana (Alanko-Kahiluoto 2007, 113114). Alanko-Kahiluoto nostaa tässä kohtaa esiin myös Levinas'in käsitteen il $y a$. Merkityksen loputtomuuden ajatuksellaan Blanchot tulee hyvin lähelle tätä Levinas'in persoonattoman ja loputtoman olemisen ajatusta (Alanko-Kahiluoto 2007, 115). Blanchot erottaa toisistaan kuolemisen (le mourir) ja kuoleman (la mort). Kuoleminen on jotakin vahvempaa kuin kuolema (Blanchot 1995, 47). Blanchot kirjoittaa, kuinka kuolema on mahdoton, koska se on mahdoton minulle: se on väistämätön mutta tavoittamaton. Kuolema on se, mikä ei koskaan yllä minuun asti, se mille en koskaan voi sanoa "Kyllä". "Se on nykyhetken kuilu, nykyhetketön aika, johon minulla ei ole minkäänlaista suhdetta, aika jota kohti en voi rientää, sillä minä en kuole kuolemassa [...] sillä kuolemassa kuollaan, kuollaan lakkaamatta, loputtomasti" (Blanchot 2003, 131). Alanko-Kahiluodon mukaan kuoleman pakenemisen liike vastaa kirjallisuuden liikettä. Emme voi päästä käsiksi taiteen keskipisteeseen, hetkeen ennen nimeämistä, taiteeseen alkuperänä, kuten emme voi päästä käsiksi kuolemaankaan. Kuoleman hetki pakenee otteestamme, kielen on mahdoton saavuttaa sitä. Tänä äärimmäisenä ulkopuolena kuolema on Alanko-Kahiluodon mukaan kuitenkin Blanchot'lle kaiken merkityksen ehto. Merkityksen loputtomuutena kielestä ei ole tietä ulos, ja siksi sen merkityksen tuleekin löytyä siitä itsestään. (Alanko-Kahiluoto 2007, 114-115.)

Kirjallisessa avaruudessa Blanchot kirjoittaa kysymyksestä, joka on kirjallisuus itse: "Mikä teos on? Mikä on teoksen kieli? Kun kysytään, 'onko jotain kaunokirjallisuuden kaltaista olemassa?', kysymys on itse kirjallisuus: se on kirjallisuus, joka on muuttunut huoleksi omasta olemuksestaan." Blanchot'n mukaan tätä kysymystä ei voi jättää syrjään. Kirjallisuus siis pyrkii kysymään itseltään: mitä kirjoitettaessa tapahtuu? Mitä seurauksia on tosiasialla, että jotain sellaista kuin kirjallisuus on olemassa? Ja lopulta voidaanko sanoa, että jotain kaunokirjallisuuden kaltaista on olemassa? (Blanchot 2005, $37-$ 38.) Jo esseessään "Kirjallisuus ja oikeus kuolemaan" Blanchot kirjoittaa, kuinka kirjallisuus syntyy silloin kun siitä tulee kysymys, oma kysymyksensä (Blanchot 2001, 14). Alanko-Kahiluodon mukaan tämä ajatus on Blanchot'n kirjallisuuden kielen tavoittelemisen lähtökohta: kirjallisuus etsii omaa alkuperäänsä, ja sitä on ajateltava omana alkuperänään. Blanchot haluaa väistää essentialisoivat kysymykset muotoa mitä on runo tai mitä on taide: kirjallisuudella ei ole olemusta, joka voitaisiin pakottaa objektin muotoon. Kirjallisuutta ei voida lähestyä kysymällä Sartren tavoin "mitä on x", koska se itse toimii kysymyksen muodossa. Kirjallisuutta on lähestyttävä ei-objektivoi- 
van asenteen turvin. Kirjallisuus omana kysymyksenään merkitsee Alanko-Kahiluodon mukaan Blanchot'lle ajatusta siitä, että kirjallisuuden olemusta ja mahdollisuutta on tavoiteltava siitä itsestään käsin; ei sen henkilön tietoisuudesta, joka kirjallisuuden mahdollisuutta kysyy. (AlankoKahiluoto 2007, 41-42.)

Alanko-Kahiluoto rinnastaa Blanchot'n kysymyksen kirjallisuudesta omana alkuperänään Heideggerin ajatukseen filosofiasta oman itsensä kysymisen ja kyseenalaistamisen lähteenä. Heideggerin mukaan filosofia alkaa kun se kysyy omaa olemistaan, olemisen mieltä (Alanko-Kahiluoto 2007, 41-42). Heidegger ulottaa filosofisen kysymisen taiteeseen: nimenomaan taiteen avulla voidaan lähestyä kysymystä olemisen mielestä, taideteoksen kysyessä omaa alkuperäänsä. Tärkeässä taidetta käsittelevässä teoksessaan Taideteoksen alkuperä Heidegger pyrkii osoittamaan, että taiteen olemus ja olemisen problematiikka ovat vahvasti sidoksissa toisiinsa. Taiteessa voimme saada aavistuksen jostakin sellaisesta, jonka kanssa olemme jatkuvasti tekemisissä, mutta joka kuitenkin jää meille vieraaksi, eli olemisesta sinänsä. Kysymys taiteen alkuperästä muodostuu kysymykseksi taiteen olemuksesta, taideteos kysyy oman olemuksensa syntyä. (Heidegger 1996, 34, 13.)

Ajatuksella taiteesta omana alkuperänään sekä Heidegger että Blanchot vastustavat Alanko-Kahiluodon mukaan perinteistä esteettistä näkemystä, jonka mukaan taideteos on aina objekti, kokijan kokemukselle alisteinen katsomisen kohde. Hän löytää sekä Heideggerilta että Blanchot'lta saman halun kään- tyä pois metafyysisestä ajattelusta, joka asettaa maailman representoitavaksi objektiksi. (Alanko-Kahiluoto 2007, 4546.) Alanko-Kahiluoto osoittaa tutkimuksessaan, kuinka Blanchot ja Heidegger jakavat pitkälle samanlaisen käsityksen taiteesta, mutta kuinka Blanchot myös erottautuu radikaalisti Heideggerin ajattelusta. Sekä Heidegger että Blanchot tavoittelevat kirjallisuuden mahdollisuutta jonakin, joka voi tavoittaa tuntemattoman objektivoimatta sitä (Alanko-Kahiluoto 2007, 46), mutta tulevat sen merkityksestä lopulta erilaisiin johtopäätöksiin. Suhde kieleen siis sekä yhdistää että erottaa Heideggeria ja Blanchot'ta.

Heideggerin mukaan taideteoksessa on kyse totuuden tapahtumisesta. Totuudella Heidegger ei suinkaan tarkoita sitä, että taideteoksessa esiintyvä asia vastaisi todellisuutta tai että se olisi esitetty jollakin tavalla oikein. Alanko-Kahiluoto nostaa esiin Heideggerin erottelun kahden totuuskäsityksen välillä: toisaalla on totuus korrespondenssina ja toisaalla totuus aletheiana (AlankoKahiluoto 2007, 142). Heidegger puhuu totuudesta aletheiana, kätkeytymättömyytenä. Totuuden tapahtuminen merkitsee, että taideteoksessa paljastuu jotain (Heidegger 1996, 38). Heidegger pyrkii selittämään ajatusta totuudesta aletheiana teoksessaan Taideteoksen alkuperä esimerkillä van Goghin maalaisnaisen kenkiä esittävästä maalauksesta: van Goghin maalauksessa paljastuu kenkien olemisen tapa tarvikkeena, maalaisnaisen kengät ovat tarvike, teos on puhunut ja olemme sen läheisyydessä olleet yhtäkkiä jossain muualla kuin missä tapaamme yleen- sä olla (Heidegger 1996, 34). Heidegger kysyy itseltään, mitä tässä tapahtuu, mitä teoksessa on tekeillä: "Van Goghin maalaus on avaus siihen, mitä tarvike, pari talonpoikaiskenkiä, tosiasiassa on. Tämä oleva astuu esiin olemisensa kätkeytymättömyyteen. Kreikkalaiset kutsuivat olevan kätkeytymättömyyttä sanalla aletheia. Me puhumme totuudesta ajattelematta juurikaan sanomaamme. Jos oleva avautuu teoksessa siihen mitä ja miten se on, niin siinä on tekeillä totuuden tapahtuminen." (Heidegger 1996, 34.)

Alanko-Kahiluoto tulkitsee Heideggerin ajatuksen totuudesta aletheiana avaavan mahdollisuuden vähemmän väkivaltaiseen näkemiseen. Totuus aletheiana ei pyri saavuttamaan jotakin "käsilläolevaa", vaan se on pikemminkin olemisen tapahtumisen ajattelua (Alanko-Kahiluoto 2007, 43). Heideggerille "totuus on olemisen totuus" (Heidegger 1996, 85). Alanko-Kahiluoto esittää, että Heidegger ei enää Platonin tavoin samaista totuutta valoon ja näkemistä tietoon, vaan Heideggerille totuus aletheiana on kaiken näkemisen ja katsomisen ehto. Sitä ei voida nähdä, koska se ei näyttäydy meille objektina eikä se ole riippuvainen väitelauseiden totuudesta. Ontologisella analyysillään näkemisestä Heidegger tavoittelee uudenlaista näkemistä, joka ei ole enää perustu tekemiseen läsnäolevaksi ja joka auttaa meitä suhtautumaan avoimemmin olemiseen. (Alanko-Kahiluoto $2007,142-143$.)

Alanko-Kahiluodon mukaan Heidegger näkee runouden ei-väkivaltaisena keinona saavuttaa totuus olemisesta. Runous on Heideggerille paikka, jossa totuuden on mah- 
dollista ilmetä. Totuudenmukaisempana "näkemisenä" runoudesta tulee Heideggerille vähemmän väkivaltaisen kielen mahdollisuus (Alanko-Kahiluoto 2007, 181-182). Tässä ilmenee ratkaiseva ero Blanchot'n ja Heideggerin välillä. Blanchot ei usko eiväkivaltaisen kielen mahdollisuuteen, vaan myöntää kielen monimielisenä sisältävän sekä väkivaltaisen että ei-väkivaltaisen puolen (AlankoKahiluoto 2007, 119). Alanko-Kahiluoto painottaa, että siinä missä Heideggerilla runous lopulta onnistuu tuottamaan olemisen totuuden, Blanchot'lla taideteoksessa ei ole kyse totuuden tapahtumisesta, olkoonkin että Heidegger ymmärtää totuuden aletheiana eikä korrespondenssina (Alanko-Kahiluoto 2007, 146). Blanchot'n myöntämästä kielen yhtäaikaisesta väkivaltaisuudesta ja ei-väkivaltaisuudesta seuraa Alanko-Kahiluodon mukaan, että kieli jää kokonaan erottelun totuusepätotuus ulkopuolelle: se ei pysty eikä sen pidäkään tavoitella totuutta (Alanko-Kahiluoto 2007, 169). Puhuminen taiteesta totuutena tarkoittaa, että se on alisteinen jollekin itsensä ulkopuoliselle. Blanchot'lle taide ei ole alisteinen totuudelle eikä millekään muullekaan, vaan taiteessa on kysymys puhtaasti sen oman olemuksen etsimisestä (Alanko-Kahiluoto 183).

Jos kirjallisuuden tehtävä ei ole hegeliläinen käsitteellistäminen eikä myöskään heideggerilainen totuuden paljastaminen, mikä se sitten on? Alanko-Kahiluodon tutkimuksen johtopäätös on, että Blanchot'lla se on kieltäytyä sanomasta mitään (Alanko-Kahiluoto 2007, 33.) Mitä Blanchot tällä tarkoittaa? AlankoKahiluodolle Blanchot'n kir- jallisuudenteorian tarkoitus on haastaa sekä Hegelin että Heideggerin ajatukset kielestä nimeämisenä. Siinä missä $\mathrm{He}-$ gelin mukaan kieli nimeämisenä perustuu käsitteellistämiselle ja onnistuu lopulta paljastamaan olemisen totaliteetin ihmiselle, Heideggerille nimeäminen ei ole hegeliläistä jo jonkin olemassaolevan asian paljastamista. Heidegger ajattelee, että nimeämisen tapahtuma saa jonkin asian tulemaan esiin ensimmäistä kertaa. Kieli antaa olemassaolon jollekin sellaiselle, mitä aikaisemmin ei ollut olemassa. Heideggerilla runous nimeämisenä saa olemisen ilmenemään, se luo olemisen. (Alanko-Kahiluoto 2007, 188-189.)

Alanko-Kahiluoto tulkitsee Blanchot'n tavoittelevan kirjallisuuden kieltä, joka jäisi kokonaan tämän kahden nimeämisen tavan välisen erottelun ulkopuolelle (AlankoKahiluoto 2007, 32-33). Blanchot'n mielestä sen sijaan, että jäisimme edelleen läsnäolon metafysiikan kielenkäytön vangeiksi, meidän tulisi kysyä kysymys, jonka filosofianhistoria on unohtanut (Blanchot 1993, 16): kysymys siitä, mitä katse ei voi tavoittaa, siitä mikä onnistuu pakenemaan katseen alistavaa voimaa. Blanchot'lle kysymys on kirjoittamisesta ulkopuolena ja neutraalina, kirjoituksen persoonattomana ja loputtomana jatkumisena. AlankoKahiluoto pitää Blanchot'lle keskeistä ulkopuolen kokemusta jonakin, mitä filosofinen ajattelu ei pysty tavoittamaan. Näin on sikälikin, että Blanchot jättää määrittelemättä ulkopuolen käsitteen, ja tämä tekee sen analyysista verrattain hankalaa. Alanko-Kahiluodon mukaan voidaan kuitenkin sanoa, että ulkopuoli kohdataan Blanchot'lla aina kirjallisuuden kielen kautta ja siinä itsessään. Kirjallisuuden kieli voi tuoda ulkopuolen esiin määrittelemättä sitä. Alanko-Kahiluoto kirjoittaa, että Blanchot'n näkemisen ylivallan kritiikki on samaan aikaan ulkopuolen puolustus, näkemisen ylivalta on aina suhteessa ulkopuolen problematiikkaan (Alanko-Kahiluoto, 35-36). Blanchot'n on mahdollista puhua toisesta ainoastaan ulkopuolena ja ulkopuolella. Kieli ei nimeä ulkopuolta, vaan se on itse tämä ulkopuoli (Alanko-Kahiluoto 2007, 217).

Alanko-Kahiluoto osoittaa tutkimuksessaan, että Blanchot'n mielestä Heideggerin ontologia ei onnistu löytämään kieltä joka olisi vapaa metafyysisistä ennakko-oletuksista. Totuuden vaateellaan Heideggerin ontologia on Blanchot'n mukaan edelleen muotoiltu metafysiikan kielellä (Alanko-Kahiluoto 2007, 2728, 147; Blanchot 1993, 439, n. 3). Alanko-Kahiluoto painottaa, että siinä missä Heideggerille kieli on alisteinen kysymykselle olemisen mielestä, Blanchot'lle kysymys kielestä kirjallisuutena on ensisijainen (Alanko-Kahiluoto 2007, 44). Ainoastaan asettamalla kieli omaksi lähtökohdakseen Blanchot'n on mahdollista luoda käsitys kirjallisuuden kielestä, joka ei kiellä eikä myönnä olemista sinänsä, vaan on kokonaan olemisen ja ei-olemisen metafyysisen vastakkainasettelun ulkopuolella (Alanko-Kahiluoto $2007,200,208)$. Fragmentaarinen kirjoitus mahdollistaa vähemmän väkivaltaisen kielen: kielen, joka ei perustu katseen ja ajattelun ylivallalle (Alanko-Kahiluoto 2007, 39). Fragmentaarinen kirjoitus on määrittelemätöntä kir- 
joitusta, joka ei ole runoa tai proosaa, vaan se on niitä molempia.

Kirjallisessa avaruudessa Blanchot kirjoittaa lumoutumisesta. Juuri lumoutumisen käsitteen avulla Blanchot Alanko-Kahiluodon tulkinnan mukaan haastaa läsnäolon metafysiikan, idean kirjallisuuden kokemuksesta näkemisenä (Alanko-Kahiluoto 127). Hän käyttää Thomas l'Obscuria esimerkkinä Blanchot'n lumoutumisen maailmasta. Tarinassa Thomas itse eli lukija ei kontrolloi omaa lukemistaan, vaan viettelevällä voimallaan teksti lumoaa hänet. (Alanko-Kahiluoto 2007, 131.) Alanko-Kahiluodon mukaan lumoutumisen käsite paljastaa eron Blanchot'n ja Heideggerin ajattelussa; toisin kuin Heidegger, Blanchot ei usko, että kirjallisuus pystyisi opettamaan meille miten "nähdä" maailma tai oleminen toisin. Alanko-Kahiluodon ajatus on, että Blanchot'n kirjallisuuden kokemus lumoutumisen kokemuksena ei ole paljastamista tai oppimista. Lumoutumisen kokemuksena kirjallisuus jää kokonaan erottelun näkeminen-ei-näkeminen ulkopuolelle (Alanko-Kahiluoto $2007,190,39$ ). Blanchot itse kirjoittaa, kuinka "se, mikä lumoaa, riistää kyvyn antaa asioille mieli" (Blanchot 2003, 28). Blanchot siis ei väitä ajattelevansa selittämätöntä vaan lumoutuvansa sen voimasta. Kirjallisuus ei ole Blanchot'lle selittämistä tai puhdasta käsittämistä, vaan selittämätön ilmenee siinä (Blanchot 2001, 26). Blanchot'n fiktiiviset kertomukset tavoittelevat jotakin, joka ei voi ilmetä sellaisenaan ja jota voi yrittää tavoitella ainoastaan käsitteellistämättä ja nimeämättä, pakottamatta sitä objektin muotoon (Alanko-Kahiluoto 2007, 68).
Alanko-Kahiluoto väittää lopulta tutkimuksessaan, että Blanchot'lle kirjallisen kielen tehtävä on kysyä, miten puhua ilman, että sanoo mitään (Alanko-Kahiluoto 2007, 224). Tämä onnistuu vain, jos kirjallisuus ymmärretään radikaaliksi ulkopuoleksi. Blanchot'n fiktiiviset kertomukset, kuten Thomas l'Obscur, sekä fragmentaarinen kirjoitustapa teoksissa L'Entretien infini ja L'écriture désastre ovat Blanchot'n välineitä tavoitella tätä ulkopuolta. Fragmentaarinen kirjoitus haastaa idean kielestä näkemisenä, paljastamisena ja ajatteluna (Alanko-Kahiluoto 2007, 39). Alanko-Kahiluodon mukaan Blanchot'n fragmentaarinen kirjoitus kyseenalaistaa metafyysisen muodon idean. Blanchot'n fragmentaarisissa dialogeissa ei ole kyse keskusteluista, joilla olisi alku ja loppu, vaan pikemminkin loppumattomasta dialogin prosessista: kirjoittamisesta loputtomuutena. (Alanko-Kahiluoto 2007, 203-204.)

Alanko-Kahiluodon mukaan kirjallisuuden tehtävä Blanchot'lla on siis yrittää tavoittaa jotakin sellaisenaan; jotakin, mikä ylittää kykymme käsitteellistää. Blanchot määrittelee kielen yhtä aikaa toiseudeksi, ulkopuoleksi mutta myös ainoaksi kommunikaation mahdollisuudeksi; mahdollisuudeksi kommunikoida toisten kanssa ja kommunikoida "toinen". AlankoKahiluodolle ratkaiseva kysymys Blanchot'n ajattelussa on, kuinka saavuttaa toinen tekemättä väkivaltaa toisen toiseudelle. Kirjallisuus radikaalina ulkopuolena ja toiseutena, vähemmän väkivaltaisena kielenä, on Alanko-Kahiluodon mukaan Blanchot'n ratkaisu tähän kysymykseen. Kirjallisuus on lopulta kirjoit- tamista toisin kuin nähdä, "writing otherwise than seeing" (Alanko-Kahiluoto 2007, 224).

Milla Härmä

K I R J A L L I S U US

Alanko-Kahiluoto, Outi 2007: $W r$ iting otherwise than Seeing Writing and Exteriority in Maurice Blanchot. Yliopistopaino, Helsinki.

Blanchot, Maurice 1995: The Writing of the Disaster. Kääntäjä A. Smock. New Bison Book Edition, London. (Alkuteos L'Ecriture du désastre, 1980.)

Blanchot, Maurice 1993: The Infinite Conversation. Kääntäjä S. Hanson. (Alkuteos L'Entretien infini, 1969.) University of Minnesota Press, Minneapolis.

Blanchot, Maurice 2003: Kirjallinen avaruus. Suomentaja S Lindberg. ai-ai, Helsinki. (Alkuteos L'espace littéraire, 1955.)

Blanchot, Maurice 2001: "Kirjallisuus ja oikeus kuolemaan" Suomentaja O. Alanko. Nuori voima 6/01, 14-28. (Alkuteos "La littérature et le droit à la mort", 1949.)

Blanchot, Maurice 1973: Thomas the Obscure. Kääntäjä R. Lamberton. (Alkuteos Thomas l'Obscur, 1941 sekä uutena versiona 1950.) Station Hill Press, Barrytown, N.Y.

Heidegger, Martin 1996: Taideteoksen alkuperä. Suomentaja H. Sivenius. Kustannusosakeyhtiö Taide, Helsinki. (Alkuteos Der Ursprung des Kunstwerkes, 1950.) 